\title{
Homenagem a Oswaldo Porto Rocha (1955-1990)
}

Oswaldo Porto Rocha foi nosso colega na década de 1980, na Universidade Federal Fluminense, onde se graduou, fez o mestrado e atuou como professor até sua morte, em 1990. Vibrante, grande conhecedor da cidade do Rio de Janeiro e muito generoso em relação ao material que reunia, Oswaldo deixou um trabalho que é um marco na historiografia sobre o Rio de Janeiro: A era das demolições, cidade do Rio de Janeiro, 1870-1920.

Inaugurando a coleção Biblioteca Carioca, o trabalho, fruto de sua dissertação de mestrado, foi publicado pelo então Departamento Geral de Documentação e Informação Cultural, órgão da Secretaria Municipal de Cultura, em 1986. Apresentava uma revisão fundamental à historiografia da cidade, marcada até então por uma perspectiva que definia o período de Pereira Passos como a "Era dos Melhoramentos".

A pesquisa de Oswaldo trazia à tona os sentidos políticos e os interesses econômicos da redefinição do espaço urbano, assim como o envolvimento de intelectuais, engenheiros e médicos sanitaristas num projeto de modernização e civilização para a cidade. A partir de perspectivas da história social inglesa, colocava no centro dessa história sujeitos quase sempre ausentes dos estudos históricos daquela época: a população pobre que era expulsa para os subúrbios ou subia os morros da cidade. Neste ponto Oswaldo também traria uma 
inovadora contribuição, pois iria incorporar ao texto historiográfico a tradição oral, as músicas populares e as fontes literárias.

A oportunidade desta homenagem chegou com seu filho Luiz Rocha, hoje aluno de História. Luiz trazia um texto inédito de seu pai, escrito conjuntamente com Maria Luiza Burlamaqui Soares Porto Rocha, "Quando a História se cala: memórias da Espanhola". Neste artigo os autores recuperam as memórias de Nelson Rodrigues e Pedro Nava sobre a Gripe Espanhola na cidade do Rio de Janeiro, em 1918, e discutem as razões de seu esquecimento na História. Oswaldo e Maria Luiza traziam novas questões para se pensar a cidade, estabelecendo um proveitoso diálogo entre História e Memória.

Esta homenagem procura exatamente recuperar algumas memórias e repensar nossas próprias trajetórias e histórias.

\author{
Martha Abreu \\ Hebe Mattos \\ Gladys Ribeiro \\ Alberto Moby \\ Ana Maria Mauad \\ Sidney Chalhoub \\ Jaime Benchimol
}

